\title{
The many challenges of fighting against enforced disappearances in Asia
}

Edition 6, 2021

Professor Tae-Ung Baik

DOI: 10.37839/MAR2652-550X6.15

The democracy movement in Myanmar is facing a critical juncture. On February 1, 2021, the military launched a coup d'état to overthrow the democratically-elected government led by Aung San Suu Kyi's party, the National League for Democracy (NLDP). The military proclaimed a state of emergency and the Commander-in Chief Min Aung Hlaing seized power. Many prominent members of the NLDP were arrested. The mass movement in Myanmar against the military coup began with peaceful demonstrations, but are now on the verge of transforming into a guerillastyle resistance.

More than 700 people have been killed by the military according to the Assistance Association for Political Prisoners, and thousands more have been reportedly arrested or attacked during the protests. The military is committed to suppressing the people's movement, and the police are demonstrating unimaginable acts of violence and oppression against those demanding freedom of expression and the restoration of democracy. The world is witnessing the military and police turning their weapons against their fellow citizens. In addition to videos of wanton violence, the police have also been recorded dehumanising arrestees by forcing them to crawl on all fours like dogs.

The United Nations and several governments including the United States have taken a strong stance on the atrocities committed by the military in Myanmar. UN human 
rights experts have urged the military to restore democracy, immediately end the violent crackdown on peaceful protests occurring countrywide and allow freedom of expression. They warned that those who are responsible for the repression and killing of peaceful protesters, as well as the detention of government officials and journalists, will be held accountable before international jurisdictions.

I was selected as a member of the UN Human Rights Council Working Group on Enforced or Involuntary Disappearances in 2015, and currently serve as its ChairRapporteur. Since the coup in Myanmar, the Working Group on Enforced Disappearances has received reports of enforced disappearances from victims' family members. I am concerned that we may end up with a plethora of cases of enforced disappearances, torture, arbitrary detention, and even murder if the situation continues to deteriorate.

Myanmar is not the only country in Asia that enforced disappearances are becoming a major concern. There are other leaders and regimes that have the mistaken notion that they can do anything to maintain their power. Regretfully, this includes using enforced disappearances as a tool to suppress the people.

In China, we have received numerous reports from family members and concerned civil society organisations that a massive number of enforced disappearances have occurred in the Xinjiang Uyghur Autonomous Region. Under the pretext of reeducation to prevent terrorism, members of the Uyghur minority ethnic group are forcibly sent to what Chinese authorities call 'vocational education and training centers', with no information on their whereabouts and fate given to their families. I have met many people from the region who are trying to find out what happened to their family members, and they are living in fear. It is especially concerning because the basis for such forced disappearances is often very trivial: for example, having relatives living abroad or maintaining international contacts could lead to an enforced disappearance. 'Residential Surveillance at a Designated Location (RSDL)' under Article 73 of the amended Criminal Procedure Law, is used against individuals accused of endangering state security, and is another issue of serious concern. 
Because RSDL places individuals under incommunicado detention without disclosing their whereabouts, it may amount to a form of enforced disappearance.

Sri Lanka has experienced more than three decades of domestic conflict, which was accompanied by various forms of enforced disappearances. It seemed that there was some hope developing because of efforts by the government to confront its history. However, recently the Government is weakening initiatives it previously started to search for and investigate enforced disappearances and has now returned to promoting a culture of impunity for these crimes.

It is also disheartening to point out that enforced disappearances are being committed in the name of counter-terrorism measures. Increasing numbers of enforced disappearances are being reported in Pakistan and Bangladesh, and it does not seem that the situation will improve in the near future. In many countries with enforced disappearance cases, human rights defenders and civil society organisations are targeted for bringing attention to the issue. They are often threatened or attacked, and perpetrators are not prosecuted. The lack of action from these governments promotes a culture of impunity and indifference.

Some enforced disappearance cases may occur in the context of complicated international disputes. For example, North Korea's abductions of Japanese nationals in the 1970s. Many South Korean citizens have raised enforced disappearance cases against North Korea as well, some of which date back to the Korean War. Transnational disappearances have occurred across the national borders of North and South Korea, Russia, China, and Japan. There are still many family members who are actively trying to find out the whereabouts and fate of disappeared persons in the Philippines, Cambodia, Laos, and many other Southeast Asian countries. We are dismayed that we find many similarities between the cases of enforced disappearances in Asia and Latin America.

Enforced disappearances became widely known to the world in the 1970s and early 1980s during the 'Dirty War' in Argentina where the Argentine military dictatorship 
committed the forceful disappearances of some 30,000 of its own citizens while denying that they kidnapped, tortured, and murdered them. To fight against these gross and systematic human rights violations, the UN Commission on Human Rights established the Working Group in 1980 as the first special procedure mechanism of the UN Commission on Human Rights.

An enforced disappearance is defined by the following constituent elements:

- Deprivation of liberty (persons are arrested, detained or abducted against their will or otherwise deprived of their liberty);

- Grounds for Governmental responsibility (by officials of different branches or levels of Government or by organised groups or private individuals acting on behalf of, or with the support, direct or indirect, consent or acquiescence of, the Government); and

- A State's continuous refusal of relevant action (a refusal to disclose the fate or whereabouts of the persons concerned or a refusal to acknowledge the deprivation of their liberty, which places such persons outside the protection of the law).

Under the Declaration on the Protection of all Persons from Enforced Disappearances (1992), the Working Group works to assist families of disappeared persons to ascertain the fate and whereabouts of the disappeared and to assist and monitor States' compliance. Additionally, with the assistance of the secretariat members based in Geneva, the Working Group monitors States' compliance, and documented cases of enforced disappearance. The Working Group receives individual petitions from victims' families and civil society members, and channels them through to the relevant governments to demand searches for the disappeared persons, investigations, and punishment for those responsible. We also press States to offer remedies, including compensation and a guarantee of non-recurrence of the violations. Since its inception, the Working Group has transmitted a total of 58,606 cases to 109 States, and as of 2020 the number of outstanding cases under active consideration stood at 46,271 in a total of 92 States. Unfortunately, the number of 
cases of enforced disappearances in Asian States is not decreasing and we are seeing a rapid increase in some countries.

Enforced disappearances can be committed in specific contextual backgrounds. First, wars, domestic or international military conflicts, civil wars, or other military activities could be the background for cases of enforced disappearances. As previously mentioned, it is very common to see enforced disappearances being reported in the contexts of past wars, such as the Korean War, the Pacific War, the Vietnam War, domestic conflicts in the Philippines, the civil war in Sri Lanka, and conflicts in Kashmir in India or Pakistan, among others. Avoiding armed conflict and promoting peace often go hand in hand with efforts to search for missing persons and the discovery of their fate.

Second, many cases of enforced disappearance are being reported in countries where campaigns for counter-terrorism activities are launched. They often emphasise public emergency and security challenges as grounds for impunity, and do not take the crime of enforced disappearance seriously. This is especially the case when democracy and the rule of law have not been firmly established. The abusive use of security forces operating with impunity under counter terrorism activities can lead to a large number of cases of enforced disappearance.

Third, enforced disappearances can be also committed by non-State actors. Although the current international law regime is focused on the actions of States, we have witnessed an increasing number of cases of human rights violations committed by non-State actors. Non-State actors often occupy part of a country's territory and act as if they are the government in those regions. The actions of non-State actors are hard to address, mainly because the official governments may be incapable of implementing national laws to provide adequate legal protection to the residents in those territories. Although the UN mechanisms are generally focused on human rights violations committed by State actors, the Working Group has decided to document and monitor cases related to non-State actors to fill in the protection gap. 
Fourth, enforced disappearances can occur in the context of migration or transnational border crossing, including acts of human trafficking or the smuggling of migrants. Disappearances may take the form of abduction for political or other reasons, along with detention or deportation processes. Enforced disappearances can also occur in the process of trans-border abduction or extraterritorial rendition.

Finally, enforced disappearances could occur in association with natural disasters such as floods, earthquakes, tsunamis, and a pandemic such as COVID-19. We have serious concerns about the impact of COVID-19 on enforced disappearances. Not only have enforced disappearances continued during the pandemic, but it has generated new contexts for enforced disappearances and has reduced the capacity of all actors to take the necessary action to search for and investigate cases of disappeared persons. Enforced disappearances should remain strictly prohibited in all circumstances, and activities such as searches and investigations should not be discontinued due to the pandemic.

The contexts of enforced disappearances that are being reported in Asian countries are not uniform. However, many Asian countries still do not understand the nature of the crime of enforced disappearance, and often believe that the issue does not have any relevance in their countries. The situation gets aggravated when it is combined with the lack of an independent judiciary, the lack of space for lawyers, human rights defenders, and civil society as actors that can hold in check the otherwise unrestrained power of agents who are responsible for carrying out enforced disappearances. One of the key reasons for the continuing practice of enforced disappearances is the culture of impunity that is often supported by the government.

All States should make it clear that they bear the obligation to search for the disappeared, to investigate the crime of enforced disappearance, to protect the rights of the victims and their families, and to provide remedies including truth and reconciliation amongst the relevant parties and the creation of new institutions to prevent the situation continuing. 
To protect the right to be free from enforced disappearances, the international community adopted the International Convention for the Protection of all Persons from Enforced Disappearance in 2006, which became effective in 2010. However, the number of participating states is still very low compared to other treaties. Among 63 Member States of the treaty, only eight states from the Asia-Pacific region have ratified or acceded the treaty and, only four East Asian states-Cambodia, Japan, Mongolia, and Sri Lanka have ratified it

Asian countries should consider their obligations and responsibilities more seriously and reject a culture of impunity in order to eradicate enforced disappearances. They should also understand that their domestic criminal law systems are not sufficient to deal with the crime of enforced disappearance. An enforced disappearance is a continuous crime that needs a comprehensive approach to fight against it.

While working as an expert for the UN Human Rights Council's Working Group for the past five years, I have come to understand that one of the most tragic dimensions of the crime of enforced disappearance is the suffering that is inflicted on the people who know the victims. Enforced disappearance is a serious crime that goes against the philosophy of humanity. The pain and suffering of the family members do not end until they find out the fate or whereabouts of their loved ones. Bottles of water and facial tissues should always be readily available when interviewing the family members of the disappeared persons because their stories cannot be told without tears.

Mothers looking for sons, wives looking for husbands, and the children looking for parents demonstrate the endless chain of tragedy in our contemporary world. This human atrocity must end immediately. I hope that the international community will strengthen its efforts to eradicate enforced disappearances as soon as possible.

This article was supported by Strategic Research Institute Program for Korean Studies through the Ministry of Education of the Republic of Korea and Korean Studies Promotion Service of the Academy of Korean Studies (AKS-2020- 
SRI-2200001).

Related webinar: Human rights and democratic regression in Asia.

Image credit: Anna Richards/Flickr. 